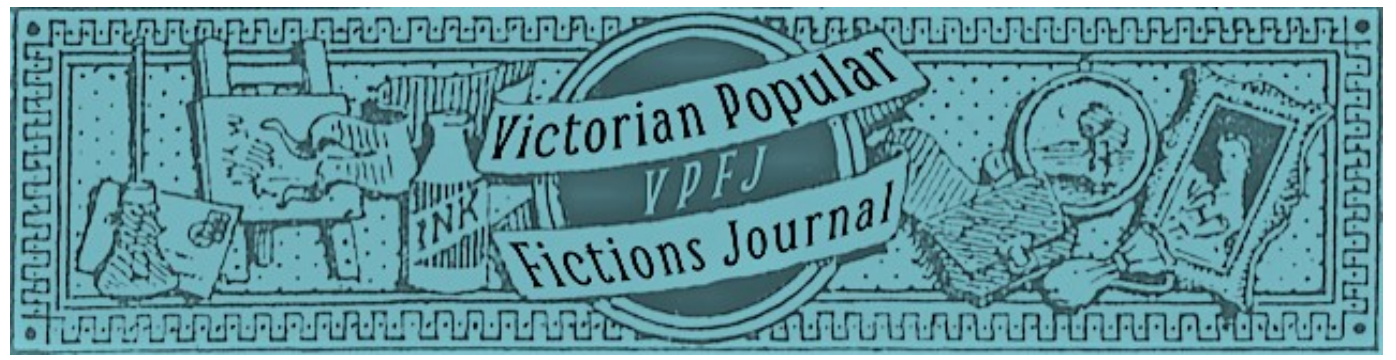

\title{
With Gordon, Kitchener and Others in the Sudan: Mapping Fictional Engagement with the Imperial Frontier
}

\author{
Luisa Villa
}

\begin{abstract}
The protracted military engagement in the Sudan (1884-99) can be regarded as the most iconic among the "little wars" late-Victorian Britain fought on its imperial frontiers. Numberless historical studies have addressed its events, its protagonists, its politics, and aspects of its immense discursive fallout. In recent years, its impact on popular literature has been discussed, most notably, in connection with the "paranoid imaginary" underlying "Imperial Gothic" fictions, with fantasies of retaliatory invasions and reverse colonisation. On the other hand, as a fictional corpus, the adventure narratives inspired more directly by the military events and the concomitant political debate have not attracted attention. Having identified ten novels - written between 1885 and 1907, all at least partly set in the Sudan - I set out to outline the development of this strain of historical/military adventure over roughly two decades, highlighting its narrative strategies in articulating the changing perception of the conflict. In order to do so, I focus on the novelists' selection, or evasion, of historical "facts," the intertwining of the factual strain of adventure fiction with the conventions of the quest romance, and the uses of their often multiple protagonists. I also foreground aspects of divergence as well as of consonance between the children's novels and those written for the general public, showing how they experimented with varying narrative takes on the same highly topical subject-matter.
\end{abstract}

\section{Key words}

adventure fiction; historical novel; juvenile literature; Sudan military campaigns; Omdurman; Khartoum; G. A. Henty; R. M. Ballantyne; A. E. W. Mason; Rudyard Kipling.

Date of Acceptance: 23 December 2019

Date of Publication: 31 December 2019

Double Blind Peer Reviewed

\section{Recommended Citation:}

Villa, Luisa. 2019. "With Gordon, Kitchener and Others in the Sudan: Mapping Fictional Engagement with the Imperial Frontier." Victorian Popular Fictions, 1.2: 61-74. ISSN: 2632-4253 (online) DOI: https://doi.org/ 10.46911/RUKL7281 


\title{
With Gordon, Kitchener and Others in the Sudan:
}

\section{Mapping Fictional Engagement with the Imperial Frontier}

\author{
Luisa Villa
}

\section{Preliminary}

A search in the British Newspaper Archive database confirms that the Sudan (or "Soudan," as it was then spelt) started hitting the news in the 1870s when the Egyptian Khedive Ismail financed a series of campaigns for the repression of the slave trade. ${ }^{1}$ Ismail hired prominent foreigners (Samuel White Baker, Charles G. Gordon, Rudolf Slatin, Eduard Schnitzer/Emin Pasha, Romolo Gessi) whose explorations and feats of derring-do put the Sudan on the map for European audiences. Roughly at the time of the bombardment of Alexandria and the British military occupation of Egypt (1882), a larger wave of interest was linked to the rise of the anti-Egyptian Mahdist political-religious movement, its leader Mohammed Ahmed, and the extraordinary military prowess of his supporters. After they annihilated the Egyptian expeditionary corps led by Colonel Hicks at Shaykan (3-5 November 1883), the British establishment felt under pressure to intervene. W. E. Gladstone, the Liberal Prime Minister, was reluctant to commit resources to helping the Egyptians retain control of their empire. But for the narrow strip of the Red Sea littoral (which was key in the control of the Suez Canal), the Sudan's interior with its deserts and equatorial swamps had no strategic importance for Britain. Gladstone even sympathised with the Mahdists, who, like the Continental patriots he had previously befriended, could be regarded as fighting against foreign domination. However, war in the Sudan offered professional opportunities to British military staff employed in the re-organisation of the Egyptian army. The British consular authorities in Egypt and hawkish elements in the Cabinet and in the press also favoured territorial expansion. In January 1884, General Gordon was sent to Khartoum to supervise the Europeans' evacuation. It was to be a matter of weeks; but things went otherwise. The ensuing military engagement entailed fifteen years of intermittent warfare, peaking in 1884-5 (with Gordon's mission, the long siege, the Relief Expedition and its failure) and in 1898-9, when the technologically superior British and British-Egyptian armies annihilated the Mahdists at Omdurman, "avenging" Gordon and forcibly "pacifying" the region.

The discursive and iconographic fallout of these events was enormous. The collective moods it stirred and articulated included mourning for Gordon, national shame for the debacle, desire for revenge, fascination with the enemy's "barbaric" prowess and embarrassment at the unfairness of modern industrialised warfare. These elements may be construed as crucial in sustaining the paranoid imaginary pervading various strands of contemporaneous popular fiction: fictions of reverse colonisation set in Britain and envisaging retaliatory invasions from abroad (Arata 1996: 107-32; Bulfin 2015); detective

\footnotetext{
${ }^{1}$ The number of occurrences per decade is 1,325 (1850-9), 2,640 (1860-9), 6,730 (1870-9), 225,318 (1880-9), 131,362 (1890-9), 55,857 (1900-9) - the best part of the latter relative to the Boer War years, after which British interest declined. After 1900 the alternative spelling Sudan starts being used; its occurrences are, however, comparatively few (British Newspaper Archive, mined on 3 June 2019).
} 
stories featuring foreign or colonial criminals (Bulfin 2015); "Imperial Gothic" stories (Brantlinger 1988: 227-53), often pivoting on archaeological retrievals, desecrations of tombs and mummies, long-buried curses, vengeful objects, or atavistic, mystically inclined fantasies of lost worlds and eternal, dangerous queens - such as Roger Luckhurst (2012) associates with the contemporary situation in Egypt and the Sudan.

The book industry, however, also marketed adventure novels that reflected the political and military realities of the Sudan campaigns and incorporated the lively public debate they ignited. Like newspapers and magazines, drawings and photographs, memoirs, theatricals and music-hall performances, ethnographic exhibitions and mass-produced items of material culture, these novels turned the Sudan campaigns into an object of pleasurable consumption. A significant part of this pleasure must have been produced by the fantasies of knowledge and control that their factual style of representation and specialised jargon provided. Their Sudan has none of the seductive charms or alien horrors associated with the East. It has indeed no mysteries, being largely coterminous with the region's often-reprinted maps - the great immemorial river, the very sparse urban centres (Khartoum, El Obeid, Berber), the immense "emptiness" dotted with exotically named battle-sites (Shaykan, El Teb, Tamai, Abu Klea, Kirbekan, Atbara, Omdurman). Knowingness regarding Sudanese life and fighting is conveyed by a handful of exotic terms (sheikh, kaffir, Hadendoa, Baggara, angareb, zerebas, bisharin), which - with British Camel Corps, Mounted Infantry, Gatling Guns and Martini-Henrys and Sudanese "Dervishes" and "Fuzzy-wuzzies" (as the Mahdi's followers and Hadendoa tribal warriors were called, respectively) - are crucial props in fictionalising the warfare of the Sudan frontier.

My corpus, which I shall deal with in chronological order to map the development of the subgenre of Sudanese military adventure fiction, comprises Lewis Hough's For Fortune and Glory (1885) and Robert M. Ballantyne's Blue Lights, or Hot Work in the Soudan (1888); followed by Rudyard Kipling's The Light that Failed (1891), G. A. Henty's The Dash for Khartoum (1891) and With Kitchener in the Soudan (1903); and finally, Arthur Conan Doyle's The Tragedy of the Korosko (1898) and A. E. W. Mason's The Four Feathers (1902). Eliza Pollard's With Gordon at Khartum (1907) - a belated specimen of the subgenre and, to my knowledge, the only female-authored novel on the Sudan campaigns - certainly deserves more attention than I have been able to grant it here. William Le Queux's The Eye of Istar (1897) and A. T. R. Threlfall's The Great Magician (1901), whose military scenes set in the Sudan serve as preludes to "Imperial Gothic" romances, are referenced only marginally.

The Sudan military adventure novels intercept a number of significant cultural and political issues. Some of them appear in studies of Victorian masculinities, war correspondence and the literature of war and violence, as well as in works on single authors (the bibliographies on Henty, Doyle and Kipling are extensive), but collectively they have not attracted attention. ${ }^{2}$ Though not a monolithic fictional corpus, they certainly repay close scrutiny as a distinct subgenre of historical adventure narrative. By comparing and contrasting their redeployment of journalistic and historical material, their selection of "facts," their narrative solutions, and some of their recurrent themes, I offer a survey of their development over two decades, while highlighting the not-at-all straightforward relationship

\footnotetext{
${ }^{2}$ Kestner (2010: 85-90; 111-18) includes sections on Kipling's and Mason's novels; Mallett (2015: 160-3) discusses Kipling's; Floothow (2007) covers, among other children's war fictions, Blue Lights and The Dash for Khartoum; White (1993: 48) mentions With Kitchener in the Soudan, while Bristow (1991: 147-53) and Paris (2000: 62-3) deal with it at some length; Griffith, who studies New Journalism, pays considerable attention to Henty and Kipling as journalists, and focuses on The Light that Failed (2015: 47-52), but only nods at Henty's Sudan novels. My previous research has dealt with some of these issues (Villa 2007a, 2007b, and 2009: 115-63).
} 
between imperial politics and military adventure fiction.

\section{5-90: Facts and Fictions}

The failure of the Gordon Relief Expedition had few practical consequences for Britain, but was certainly as traumatic an event as could be experienced by the world's greatest power on its imperial frontiers. Professional novelists often wrote in the wake of military engagements; but wading through the flood of information, polemics and passions related to the 1884-5 military campaign, and defining their narrative take, must have been especially challenging. Besides, the late-nineteenth-century market for military literature was highly competitive, and novels vied for readers with war correspondence, which was often republished in book form, with maps, battle plans, illustrations and documentary appendices. War correspondents themselves were celebrities whose reportage, laced with personal anecdotes, read like fiction while delivering "authentic" experience. Autobiographical accounts (diaries, letters, memoirs) by high-ranking officers and eyewitnesses were also on offer, even including A. Egmont Hake's edition of Gordon's Khartoum journals published in the summer 1885. With so many first-hand accounts of Mahdist Sudan, fictional Sudanese adventure was commercially disadvantaged. One response to this was for novelists to target a niche audience of juvenile readers. By the mid-1880s, G. A. Henty, the main practitioner of the genre, had already perfected his novelistic "formula" (Richards 1989: 75) that sent a British youngster abroad to learn about the world, meet important historical figures and distinguish himself. Henty came from the ranks of war correspondents, which accounts for his dexterity in telling military stories, plundering history books, and skilfully interweaving "facts" and "fictions." Even so, he took some years to negotiate the Sudan material, and it was a lesser-known writer who inaugurated the subgenre.

Lewis Hough's For Fortune and Glory - published in autumn 1885 - established a template subsequently redeployed by others. Hough adapted Henty's formula to Sudanese adventure, deploying three youths, just out of public school, variously engaged in the war, a strategy that allowed him to negotiate the complex logistics of the military operations while including a range of experiences and momentous episodes, dating from Hicks's rout at Shaykan (3-5 November 1883) to the battle of Tamai (13 March 1884), from Abu Klea (17 January 1885) to Kirbekan (10 February 1885). One of his heroes, suddenly impoverished, has to leave school and work as a clerk in a firm trading with the Sudan, while another having failed his competitive examination - enlists as a humble private. This makes for different ways of approaching the war, allows for a degree of dialogical confrontation between contrasting views, and (as is often the case in juvenile masculine adventure) renders the young gentleman hero available to a wider range of readerly identifications.

In describing his historical events, Hough seems to have relied on official communiqués, newspaper accounts and war correspondence. Bennet Burleigh, the Daily Telegraph "special," had famously reported from the Eastern front (February-March 1884), and his war correspondence, Desert Warfare, had become available in book form in September 1884. Hough is likely to have drawn on it, in Chapter 15, in his detailed fictional representation of the battle of El Teb. In fact, two battles were fought at El Teb in February 1884. On 4 February, the numerically superior Egyptian army, led by General Valentine Baker and staffed with British officers, was routed, losing - in Winston Churchill's estimate - more than two thousand men (Churchill 1899: 77-8). On 29 February, the British troops lost hardly two hundred, while killing three thousand. The first battle's humiliating debacle, blamed on the Egyptian battalions, is only parenthetically mentioned in the novel (Hough 1885: 201). The second, being more hearty and "picturesque," is fully fictionalised, featuring 
some of the officers who had distinguished themselves in the fray, in particular F. G. Burnaby (now famous from James (Jacques) Tissot's 1870 portrait) who would die at Abu Klea where the Mahdist forces broke the square. At El Teb the square was not broken but Hough was still able to depict exciting close encounters with the enemy such as would satisfy reader expectations. Hough didactically describes the square formation, reports on narrow escapes and describes the enemy "transfixed" by bayonets, shot at close range, or comfortably mowed down from afar, as "the machine-guns sent their continuous streams of bullets tearing through the dense masses, and volleys from the Martini-Henrys ran the death list up still higher" (Hough 1885: 227). Regret is expressed that so many brave "foes" should die, "[b]ut it could not be helped: they would not fly, and they would not surrender" (Hough 1885: 226). In descriptions of Sudanese warfare, victory over valiant "barbaric" hosts tends to be a bittersweet, technological affair.

Representation of the battle of Shaykan provided narratorial and factual challenges (Villa 2007a: 41-2). It had taken place in remote Kordofan, European members of the expeditionary corps had all died, and the news had taken some three weeks to reach Cairo. Information on the battle would be pieced together from fragmentary accounts over the next fifteen years. There were rumours of the recovery of officers' or journalists' diaries and of one British survivor. These would be turned to good use in Henty's With Kitchener in the Soudan, where the imaginary survivor's diary helps fictionalise some crucial $1883-5$ events, Threlfall's first-person narrator in his novel The Great Magician having in the meantime provided an impressive fictional account of the battle. Hough dispenses with narrative complications and eschews detail. His Harry Forsyth joins Hicks's army as a voluntary cadet, is injured and gets lost in the desert, and only catches "a glimpse [of the] tragedy" from afar (Hough 1885: 138). To escape, he kills a Sudanese warrior, steals his accoutrements and sets off for El Obeid, a narrative solution that Henty will also use in his 1903 novel.

Hough's novel was praised for its graphic description of battles and truthful treatment of "many aspects of soldiering" ("Christmas Books for Children" 1885: 777). At a time when most male Britons, young and old, were directly or vicariously exposed to military practices of some sort (drills at school, youth organisations, auxiliary forces, volunteer corps) and were well-versed in military technologies and jargon (Fulton 2009: 43), verisimilitude and accuracy were expected in respectable juvenile fiction. Besides, vocational education - based on the acquisition of technical skills and related vocabulary - was in store for most of the young readers from the lower-middle-class professional ranks. Together with geography (a staple ingredient in post-1870 educational policies) (Bristow 1991: 19-21), such knowledge is enhanced and glamorised in this type of fiction. Like other modern popular narratives (sailors' stories, Robinsonades, merchants' and explorers' adventures, or even latenineteenth-century invasion fictions, with their deployment of military expertise), the subgenre connects with the "democratic" "how-to-do-it strain of adventure," which Green traces back to Defoe and contrasts with "aristocratic" romance (Green 1980: 203).

Reviewers also acknowledged, however, that to produce his "stirring tale, full of life and adventure," Hough had to resort to some "improbabilities" ("Christmas Books" 1885: 2). Indeed, his novel's very title suggests that against the background of stark factuality, technical know-how and military jargon, the diegesis relies on the fantastic conventions of quest romance, including chivalric values (courage, honour, fairness, gentlemanly behaviour), the fascination with danger, and a plot leading to a gratifying ending. The main character's quest pivots on a will stolen (in Ireland) by a devious Egyptian clerk, and requires for its completion an Irish Orientalist uncle who has gone native and has become a Mahdist sheikh, and a signet ring, which allows his nephew to be recognised and survive in a hostile environment. Fanciful as it appears, this makes the Irish Question - the other key political 
concern of the $1880 \mathrm{~s}$ - of some relevance to the story, and allows some space for the articulation of dissident views concerning war and British imperial policies. The novel, however, is quite matter-of-fact, with no undue deployment of imperialist rhetoric. Gordon is dead, after all, and the Sudan is lost; but pessimism and defeatism are duly kept at bay. One of the protagonists - the young officer - stays on in the region, while, back in England, the other two enjoy domestic peace. One considers re-enlisting, though he has lost his little finger in a fray (he is, in fact, still recovering from multiple injuries in the care of an affectionate native nurse).

The faithful African retainer who follows the hero to Britain, serving as a foil to devious foreign intruders or ungrateful natives, was part of the Henty package and would reappear in Henty's Sudan novels. Mutilation, as a bodily inscription of the historical trauma and included almost as an afterthought in Hough's story, figures more conspicuously in later Sudan fictions. The storyline of Robert Ballantyne's earnestly educational Blue Lights, or Hot Work in the Soudan (1888) is very conventional: it involves Miles Milton, a middle-class youth of nineteen who wants to join the army and quarrels with his father on that account. Miles runs away from home, enlists, and, on his voyage to Egypt, gets to know a worthy British damsel who provides moral inspiration and will eventually marry him; the novel also shows how he copes with the warlike Sudan, with fighting, imprisonment, enslavement, wearing native clothes, and escape. The author, however, quietly subverts this familiar script to produce a rather unusual experiment in antimilitaristic adventure fiction.

As to be expected, Ballantyne subscribes to accuracy and verisimilitude ("it may be well to add that most of the important incidents herein narrated are facts, and nearly all the remainder are founded on fact") (Ballantyne 1888: Preface), and declares his unglamorous sources: Miss Sarah Robinson, a philanthropist from Portsmouth (where some early episodes are set), and private Richard Stevens, Royal Marine Light Infantry, who has allowed the author to make use of the journal he kept while in Egypt and the Sudan. The novel fictionalises the short, bloody and ultimately purposeless campaign fought in the Suakin area by General Graham's expeditionary corps in spring 1885, after the fall of Khartoum and shortly before the troops were withdrawn from the region. The narration includes two or three military engagements, the best-known being the battle of Tofrek of 22 March 1885, during which the enemy managed to break into General McNeill's zereba (square-like camp). A victory for the British who left thousands of Sudanese to rot on the ground, it nonetheless had no positive issue and could fairly stand as an emblem for the "madness of warfare" (Ballantyne 1888: 386).

In the first third of the novel, Ballantyne chooses to enlarge upon the process of enlisting, sailing to Egypt and reaching the Suakin area, providing an instructive glimpse of charitable activities in Portsmouth, "anxious wives, mothers, and sisters" waiting for returning men to disembark or in tears at soldiers' departure, debris and ruins in bombarded Alexandria, and a shipful of "sick, wounded and invalids" at Suez (Ballantyne 1888: 57, 162). This long, dysphoric run-up to the military operations emphasises Ballantyne's choice to foreground the rank and file - the "Blue Lights" of the title being the navy soldiers who have undertaken a pledge to abstain from alcohol. That Miles enlists as a private makes military life anything but glamorous: he is surrounded by pious, humble folk who speak in dialect, reminisce about wives or worry about grandmothers, prepare for battle praying and reading the Bible, or occasionally get killed by their own weapons - as happens to "poor Gilroy" during gun cleaning (Ballantyne 1888: 194). Much is made of "duty to Queen and country" and "unflinching valour" (Ballantyne 1888: 246), but injuries and amputations are more in evidence than bravery, medals and promotions. The young hero's "soldiering days" come to an abrupt end when, in one skirmish, he "receive[s] a blow that shatter[s] his left 
wrist" and consequently loses his hand (Ballantyne 1888: 396, 391). Furthermore, the narrator and some characters underscore the moral perplexities of the conflict by voicing the Gladstonian argument that the Mahdists are patriots ("Shall we deny those men what we claim for ourselves - love of hearth and home, of country, of freedom?"), and fathers and husbands too, whose wives and children "are just as fond o' husbands an' fathers as ours are" (Ballantyne 1888: 245, 190).

Ballantyne's novel offers exceptionally graphic scenes of violence (Villa 2007b: 121-5). Though conceived as cautionary, they may have appealed to the general public's craving for crude sensations, but its old-fashioned "hearth and country" patriotism and celebration of domestic pieties did not stand a chance against the mounting jingoist tide. Kipling's The Light that Failed, by contrast, is situated at the opposite end of the ideologicalpolitical spectrum and, compared with Ballantyne's sedate turn of phrase, its narrative style is at the cutting edge of literary modernity. Written in 1890, it was published with two very different endings the following year. Its painter/war-artist hero is in the Sudan with the troops at the time of the Gordon relief expedition and is injured on 26 January, the day Khartoum falls and Gordon is killed. Back in London, he loses his sight as a belated consequence of his head wound, and (in the longer, more persuasive, version of the novel) eventually returns to die on the Eastern front, where desultory fighting is going on. Most of the novel is set in the metropolis, but the choice to foreground war-artists and war-correspondents - "sent out when the war begins to minister to the blind, brutal British public's bestial thirst for blood" (Kipling [1891] 1992: 48) - makes it crucial in our fictional corpus. In the two chapters set in the region Kipling's journalistic concision and flair for specialised jargon distil the very essence of Sudanese military adventure: the Nile, the lulls between the military engagements, the breaking of the square, the gruesome hand-to-hand fighting, the memorable ride of the blind hero on "the narrow-gauge armoured train" (Kipling [1891] 1992: 201). Most importantly, Kipling's novel intensifies the misogynistic connotations of military adventure. His Sudan is conceived as the perfect backdrop to masculine camaraderie, the solidarity of special correspondents and war artists contrasting favourably with the emotionalpsychological perils that infest British domesticity and heterosexual romance. The site for extreme masculine ordeals, Kipling's Sudan anticipates the counter-decadent socialDarwinist taste of the late 1890 s for bracing atavistic regressions. Such is the Sudan that Steevens would celebrate after Omdurman: "There are the things at the very back of life and no other to posture in front of them, - hunger and thirst to assuage, distance to win through, pain to bear, life to defend, and death to face" (Steevens 1898: 325).

\section{1-8: Fiction and Propaganda}

In the early 1890s, when the Sudan was still in Mahdist hands and Gordon unavenged, the mood was very different from the one Kipling's novel portended. At the time, the military establishment endeavoured to promote the resumption of hostilities in the region by emphasising war's civilising and pacifying potential. The propaganda campaign was largely the work of Major F. R. Wingate, the Director of Anglo-Egyptian intelligence. He authored, or co-authored, a cluster of texts - his own monumental Mahdiism and the Aegyptian Soudan (1891), Father Joseph Ohrwalder's more readable Ten Years' Captivity in the Mahdi's Camp (1891), and Rudolf Slatin's bestselling Fire and Sword in the Sudan (1895) - that highlighted the atrocities inflicted on the Sudanese tribes by the Mahdist administration, denounced as a bloody Islamic regime in need of severe correction by "civilised" nations. ${ }^{3}$ The fictions

\footnotetext{
${ }^{3}$ Ohrwalder, a Catholic priest from South Tyrol, had spent ten years as a prisoner of the Mahdi and the Khalifa (the Mahdi's chosen successor) before escaping in December 1891. Rudolf Slatin, another
} 
written in the $1890 \mathrm{~s}$, before the battle of Omdurman, belong to this climate and share in this propagandistic effort.

Conceived along the same lines as For Fortune and Glory, Henty's The Dash for Khartoum was published in summer 1892. Following the adventures of Edgar and Rupert Clinton, two temporarily separated teenage brothers, it describes military operations on the Eastern front (starting with the second El Teb battle) and in the Nile valley, with the advance of the Camel Corps and their confrontations with the enemy. The plot relies on coincidences, such as accidental meetings and the discovery of revealing letters. Like Ballantyne's, Henty's aim is pedagogic: young men should never act "in haste" and always seek the advice of their fathers, who are their "best friends" (Henty [1892] 2000: Preface). Under a misconception, Edgar Clinton runs away from public school and enlists as trumpeter to the Hussars. This fraternising with the lower orders allows him to prove his innate superiority as a "gentleman all over": he spontaneously abstains from alcohol as detrimental to his prospects of "ever rising" in the army, learns "to keep a sharp look-out over his things," necessary given his comrades" "laxer code of morality," distinguishes himself at military school, at cricket, and at saving British ladies from purse-snatchers, and impresses bullies with his "pluck" (Henty [1892] 2000: 73-105).

Like Ballantyne's, Henty's young hero is seriously injured, in this novel after bravely helping the tyrannical Corporal North at the second El Teb battle. But while North is permanently incapacitated, Edgar soon recovers completely and is recommended for the Victoria Cross in anticipation of future distinctions. A friendly sergeant warns him that, as "a young fellow pushing forward," he might incur jealousy from the older soldiers, and later defends him when the trumpet-major complains at the lad's preferment: "I think that a fellow like that ought to have a pull if only one is to get it, and I am sure the whole regiment will be of opinion that he has deserved the chance he has got" (Henty [1892] 2000: 124, 141). Henty's fictional moral order is both hierarchical and meritocratic.

Jeffrey Richards (1989) has pointed out the complex class alignments in Henty's novels. The family drama in The Dash for Khartoum stems from class envy and a changeling plot that entails that one of the two Clinton brothers (there is no knowing which) was from a modest social background. Both of them, however, are shown to be perfect "gentlemen," which suggests that nurture can overpower nature - out of keeping with Henty's usual entrenched race determinism and assiduous use of race stereotyping. This ideological inconsistency is especially evident in the shaping of his young heroes, whose gentlemanliness is accompanied by qualities not customarily associated with the upper echelons of society: thrift, industriousness, self-help, the desire to learn practical skills to improve one's chances of promotion, and the patience and application necessary to acquire them. More pronouncedly than Hough, Henty makes his lads composite icons of the normative British young male, an ideal on which - as Joseph Bristow underscores - a variety of contrasting imperatives, models and values are brought to bear (Bristow 1991: 53-70).

Politically, the novel aligns with the "reconquest" party, blaming the Gladstone administration for its irresolute course of action in rescuing Gordon and for the "dishonourable" (Henty [1892] 2000: 277) withdrawal of troops from the region. By unfolding the adventures of the Clintons in the Sudan after the fall of Khartoum, it also shows that things should and could have gone otherwise. Edgar has been enslaved by a nomadic tribe but soon impresses his master and becomes his military advisor, helping the tribe to

European prisoner, escaped from Omdurman in March 1885, and was soon appointed Assistant Director of Military Intelligence for the Egyptian Army. On the Wingate-Ohrwalder collaboration, see Zaccaria (1998) and Johnson (2008); on the Wingate-Slatin collaboration, see Johnson (2008). 
repel a Mahdist attack through superior military tactics and better weapons but also thanks to a miniature relief force of loyal tribal kinsmen who do not let down their sheikh and - unlike the British at Khartoum - arrive just in time for the decisive fray. On the other hand, Rupert, who has travelled to the Sudan as General Stewart's aide-de-camp (not a bad start for an inexperienced twenty-year-old), acquires a smattering of Arabic, disguises himself as an Arab, and ventures into enemy territory in search of his brother. Captain Clinton, their father, has authorised limitless expenditure to rescue Edgar, which positively contrasts with the bad economies of the Liberal Cabinet.

Henty's novel recalled the glorious asperities of desert fighting and the shame of Khartoum, suggesting that it fell upon the younger generation to heal the wound to national honour and accomplish the reconquest. Arthur Conan Doyle's The Tragedy of the Korosko was not especially addressed to young readers. It has, however, equally much to do with political propaganda and, as argued by Glazzard, "deploys many of [its] trappings" (Glazzard 2015: 176). It was written after Doyle's trip to Egypt in 1896, serialised in the Strand Magazine in 1897 and published in book form in 1898. By 1897, logistic and military operations in the Sudan had resumed in earnest. Kitchener had taken Dongola in September 1896, and progress was being made in laying the military railway line that would prove decisive in defeating the enemy.

The novel's first-person narrator purports to tell the "true" story of a recent "international incident" that has not hit the headlines because "there were very valid reasons, both of a personal and political nature, for holding it back" (Doyle [1898] 2003: 3): a small international party of tourists sail along the Nubian Nile, are captured by ferocious Mahdists, and are saved by the men of the Camel Corps. The issue of historical authenticity is exceptionally crucial here because the story is so clearly meant to provide justification for the reconquest; the presence of non-British characters allows the text to articulate competing views of the British military engagement in the region while at the same time showing that differences among Western attitudes and political persuasions are immaterial in the face of the Islamic enemy (Glazzard 2015). The argument that Britain's concern with Egypt and the Sudan was motivated by economic interest is articulated by an American and quickly disproved. Likewise, a sceptical French character's claim that "There are no Dervishes. They do not exist" (Doyle [1898] 2003: 13) is promptly refuted by the plot, which illustrates that the Mahdists are dangerous fanatics and that it is a blessing that British troops patrol the area. As an appreciative reviewer put it, the novel proves that in policing the region Britons simply fulfil their role as "Public Peace Preservers" ("Dr Conan Doyle's New Story" 1898: 5). Moslem foes are described as brutal and cowardly: they slaughter "the poor donkey-boys" who accompany the tourists ("hacking and hewing with a cold-blooded, deliberate ferocity"), manhandle British gentlemen with their "black paws" and "coarse fingers," and kill them without thinking twice (Doyle [1898] 2003: 37, 54-5). They also abduct white women and seem to be sexually attracted by them, a topos more commonly found in adventure and invasion stories aimed at adult audiences and topical in melodrama since at least the time of the Indian Mutiny (Sharpe 1993). A similar episode is included in Burleigh's libretto The Mahdi (For the Victoria Cross), performed in 1897-8 as a part of the Barnum and Bailey Great Show at the Olympia in London (Coombe 1994: 103). It was Diamond Jubilee year, the climax of imperial grandeur and euphoria, and the showdown with the Mahdist State was fast approaching. All was grist to the mill of the pro-war party. ${ }^{4}$

\footnotetext{
${ }^{4}$ The Mahdists' lust, cruelty, and treacherousness are also highlighted in the early chapters of William Le Queux's Eye of Istar. Published in 1897, it too partakes of the run-up-to-the-reconquest climate, and singles out the Khalifa (the deceased Mahdi's chosen successor) as a villain.
} 


\section{After Omdurman}

The Sudan novels written after the battle of Omdurman and published during or after the Boer War are the product of a very different political and cultural climate than the texts discussed above. The battle of Omdurman - where in barely four hours the British and Anglo-Egyptian contingent annihilated the twice-as-large enemy force, losing just fortyseven men and killing at least ten thousand - was the climax of the Sudan campaigns. In the immediate aftermath of Omdurman, the prevailing popular mood was festive and Kitchener's lionisation undisturbed (Fulton 2009). The battle's very one-sidedness, however, made the dynamics of modern "scientific" warfare apparent (Churchill 1972: 128) and the well-oiled rhetoric of colonial warfare obsolete (Villa 2009: 73-114; Griffiths 2015: 155-81). Gone were the fluster and glory of hand-to-hand fighting, the thrill of the occasional breaking of the square, the narrow escapes, the war correspondents' personal adventures. Enemies were exterminated from afar, journalists had to adjust to bureaucratised military operations and censorship, the chance for the individual to distinguish himself lay in misguided impulsive initiatives (as in the foolhardy charge of the $21^{\text {st }}$ Lancers at Omdurman on 2 September 1898), and logistics were more decisive than valour with railway lines serving as Britain's "deadliest weapon" (Steevens 1898: 22). Besides, since the victory had been so manifestly unfair when judged by gentlemanly standards, objections were raised to the destruction of the Mahdi's mausoleum, the profanation of his relics, and the systematic killing of wounded enemies. These accusations were early symptoms of changing attitudes toward military engagement on imperial frontiers, whose catalyst would be the second Anglo-Boer war (1899-1902).

Waged against white protestant colonists, the war in South Africa provoked more bitter political controversy than any of the "little wars" against "picturesque" tribesmen and "oriental" potentates (Krebs 2001). It was also a much more complex military affair, marked initially by calamitous defeats, and later marred by humanitarian outrage at Kitchener's practices: barbed wire barriers, the systematic destruction of farms and livestock, deportation of civilians to concentration camps. In later years, General Gordon would linger in public consciousness as a venerable imperial martyr and a morally inspirational (rather than military) hero such as is evoked in Eliza Pollard's With Gordon at Khartum (1907) and debunked in Lytton Strachey's Eminent Victorians (1918); but by 1902, when the Sudanese battlefields had become fashionable tourist destinations, desert fighting had lost much of its glamour and could only be recalled in nostalgic retrospect.

The Four Feathers, written by the prolific author (and later military officer) A. E. W. Mason after a 1901 pleasure trip to the Sudan, illustrates this point. The novel was serialised in the Cornhill Magazine in January-November 1902, and published in book form in October of the same year. Mason's story of a young British officer's cowardice and redemption is set two decades earlier. Oppressed by the fear of proving a coward in action, Harry Feversham, the heir to a military family, resigns his commission at the outbreak of the British-Egyptian crisis in 1882. The four white feathers Harry receives from three former comrades and his fiancée mark his disgrace, but he will later re-establish his reputation (and be able to return three of the feathers) by unglamorous feats of endurance and courage in Sudanese territory. The novel offers neither fighting scenes nor famous battles, which are only briefly recollected by Harry's friend Durrance:

the rush down the Red Sea, Tokar, Tamai, Tamanieb - the crowded moments came vividly to his mind. He thrilled even now at the recollection of the Hadendowas leaping and stabbing 
through the breach of McNeill's zareba six miles from Suakin; he recalled the obdurate defence of the Berkshires, the steadiness of the Marines, the rallying of the broken troops. The years had been good years, years of plenty, years which had advanced him to the brevet-rank of lieutenant-colonel.

(Mason [1902] 2001: 60)

The war, however, only brings death, blindness and imprisonment to the military characters.

Mason did not strew his fiction with facts, but in line with the subgenre's requirements, he aimed at historical accuracy in devising the novel's most memorable episode, Harry's detention in, and escape from, the infamous Omdurman prison called "Umm Hagar" ("The House of Stone"). The inhuman conditions in the prison are described in European prisoner memoirs, such as Fire and Sword in the Sudan by Rudolph Slatin (1897) whom Mason had met. Mason's main source, however, was Karl (Charles) Neufeld's A Prisoner of the Khaleefa (1899). ${ }^{5}$ A German merchant, Neufield was captured and examined by Abderrahman El Nejumi, a distinguished Mahdist strategist, and detained at Omdurman. His account includes several mentions of Joseppi, a slow-witted Bohemian baker with a sort of music-mania, who was suspected of being a spy and jailed, only later mysteriously to disappear from the prison. Mason's Harry Feversham, disguised as a demented Greek musician and intent on reaching Omdurman to free his former colleague Trench, is captured by the Mahdists at Dongola and examined by Nejumi, undergoing the same torture as Neufeld. ${ }^{6}$ In his effort to make his novelistic Sudan dovetail with its "factual" counterpart as known to British readers, Mason also reproduced various historical characters and circumstances referred to by Neufeld. The theme of blindness, by contrast, is derived from Kipling's The Light that Failed, but Four Feathers grants its hero a matrimonial happy ending, shifting the disability onto a stoical co-protagonist. It also articulates the thematic juxtaposition between the psychological complexities, small cruelties and concealed feminine rivalries that beset domestic life in Britain and the straightforward world of masculine ordeals on the imperial frontier. Overall, the novel is rather pensive in mood, as befits a storyline that ends in the late 1880s, with the fourth feather undelivered and the Mahdists still entrenched in the Sudan.

Mason's fiction contrasts emphatically with Henty's posthumously published With Kitchener in the Soudan. Henty's novel is likewise concerned with the idea of reparation but is pervaded by an almost manic preoccupation with thoroughness and an exultant mood of finality. The author's Preface makes it clear that the novel is meant as a homage to Kitchener, "the moving spirit" of the campaign of 1897-8, "the man whose marvellous power of organization had secured its success," and to Wingate, "his worthy successor," who chased and "routed with ease" the enemy after Omdurman; Henty is especially enthralled by the "completeness" of the "stupendous" "crushing out of the last spark of opposition" (Henty [1903] 2003: v-vi). Indeed, his novelistic account of the Sudan saga seems to vie in thoroughness with Kitchener's and Wingate's military achievements, as well as with Churchill's monumental The River War (1899). Following his customary half-fictional, halfinformative recipe, Henty squeezes into the early chapters the riots in Alexandria and the bombardment of its fortifications by the British, then includes the most memorable episodes

\footnotetext{
${ }^{5}$ I differ here from Giddings (1991) and Kestner (2010: 112), who consider Slatin Mason's main source.

${ }^{6}$ In the novel, the Mahdist soldiers "poured water upon the palm-rope which bound his wrist, so that the thongs swelled and bit into his flesh" (Mason [1902] 2001: 171). The same treatment was inflicted on Neufeld, who describes it in more detail (Neufeld 1899: 73).
} 
of the Sudan campaigns, up to the lesser-known post-Omdurman military episodes (Gedaref, Rosaires), and the Khalifa's death and his followers' surrender at Umm Dibaykarat (25 November 1899).

It takes much adroit narrative manipulation to compress so much historical information into a readable novel. Henty manages this by means of a plot straddling the generational divide and involving two heroes, Gregory Hilliard Hartley and his son, Gregory Junior. The upper-class father is an Orientalist intellectual: estranged from his family because he has married a governess, he drops his surname and emigrates with his wife to Egypt in 1881. In 1883 he joins Hicks's expeditionary corps as an interpreter and is believed to have died at Shaykan. His son, born and brought up in Egypt, enlists in the reconquest campaign in 1897, participates in all the important operations, and duly distinguishes himself. By fortuitously recovering his father's diary, he learns how Gregory Senior escaped from Shaykan, lived in disguise at El Obeid, reached Gordon in besieged Khartoum, and was killed with Stewart at Hebbeh. Young Gregory also learns his real name, thus reconfiguring his personal identity as the descendent of a noble lineage and rightful heir to the family title. The national military history of mournful loss and glorious recovery/reparation finds its equivalent in the personal experience and fulfilled quest of the young protagonist.

It also takes skill to spin a hearty yarn out of the 1897-8 campaign, with its impersonal "scientific" warfare and genocidal bent. While many of Gregory Junior's activities are not especially heroic, he also volunteers to disguise himself as a native, enters enemy camps to spy on them, and jumps into the Nile to save the Khalifa's son's favourite wife. He is consequently spared by the Mahdist leader and imprisoned at the Atbara. Eventually, he is left at the edge of the camp, "fastened ... to the stump of a tree" (Henty [1903] 2003: 185), waiting to be killed by the hail-storm of friendly British fire, only to be saved by his devoted native servant. The clash between factual accuracy (mass extermination) and quest romance with its unlikely circumstances and its focus on the individual hero could hardly be more striking. Likewise, Henty's reworking of the mutilation topos appears both ingenious and mystifying. The permanently maiming injury is here displaced onto a young Mahdist fighter - the son of an Emir - wounded at Shaykan and ailing in El Obeid. Gregory Senior, disguised as a native, pretends to have imbibed medical knowledge from British doctors and, with the providential help of surgical instruments and chloroform, saves him from gangrene by amputating his arm under anaesthetic. Unlike contemporary war correspondents and novelists, Henty was usually averse to showing his young readers the ravages of war on the human body. Here, however, the operation is described at some length (Henty [1903] 2003: 290), thus providing, as argued by Bristow, "the physical detail missing from the [novel's] battle scenes" in the guise of "an act of charity" (Bristow 1991:152).

Last but not least, Henty's crucial innovation on the previous Sudanese narratives is the young protagonist's colonial birth and upbringing. Gregory Junior's usual Hentyian profile of sedulousness, enterprise and gentlemanly stamina is enriched by the fact that he has grown up in Egypt and is endowed with a perfect knowledge of Arabic and various Sudanese dialects. This allows him effortlessly to pass for a native, travel undisturbed in enemy territory, converse with Mahdist Emirs and their wives, and even persuade them sensibly to surrender. Kipling's Kim had come out in 1901 and might have alerted Henty to the fictional potential of such a hybrid character who could incorporate/neutralise Sudanese otherness.

Kim's influence is also perceivable in Pollard's With Gordon at Khartum, which features among its protagonists a perfectly bilingual orphan child born in Egypt, who "frequently goes about in a native dress" (Pollard 1907: 90) looking for his lost little sister, picking up information for Gordon and the Anglo-Egyptian authorities. Pollard's deployment of the Kim-like urchin is, however, the very opposite of Kipling-esque, her novel being a 
gallant attempt to re-connect the hyper-masculine sphere of Sudanese adventure to the feminine sphere of domestic ties, with sisters, wives and mothers being as much in evidence as their male counterparts. This produces an alternative take on the Sudan campaigns, but results in a mid-Victorian ethos, with its emphasis on duty, focus on missionary and clerical families, interest in the slavery question, and pronounced earnestness.

\section{Conclusion}

The novels inspired by the protracted military engagement in the Sudan fictionally articulated changing perceptions of the conflict over roughly two decades. My chronology underscores significant discontinuities between the fictions of the 1880s, whose main concern was with the specificities and moral implications of the Sudan war (episodes of hand-to-hand fighting alternating with mass-slaughter), and the fictions of the 1890s, which participated in the propaganda campaign for the "reconquest" and were chiefly preoccupied with deploring the mistakes of the Gladstone administration and denouncing Mahdist atrocities. A further watershed is represented, at the turn of the century, by the battle of Omdurman and the Boer War: both the one-sidedness of the victory over the technologically disadvantaged Sudanese and the complexities of modern warfare against the South African white colonists contributed to making the Sudan war narratives obsolete.

In analysing this corpus, I have deliberately sidelined the political opinions voiced by characters and narrators, which confirm their authors' awareness of the discursive fallout of late-nineteenth-century imperialism (inclusive of arguments against expansionist foreign politics). Rather, I have focused on the novelists' selection, or evasion, of historical "facts," the intertwining of the factual strain of adventure fiction with the conventions of the quest romance, and the novels' frequent introduction of multiple protagonists: deployed to tackle the war's various stages and dispersed logistics, they also make for different perspectives on, and a more nuanced approach to, the events narrated. I have also foregrounded aspects of divergence as well as of consonance between children's novels and those written for the general public, showing how this body of fiction experimented with a gamut of narrative takes on the same highly topical subject-matter. One recurrent topos in the corpus is disability as a bodily inscription of the irreversible historical trauma: minimised in the first novel written after the fall of Khartoum, it is enlarged upon and variously accommodated in most of the other fictions, eventually figuring - after Omdurman - as inflicted therapeutically on the Arab body or, alternatively, shifted onto an expendable co-protagonist.

In the twentieth century, the Sudan saga as popular entertainment migrated onto the screen, with multiple adaptations of The Four Feathers and Basil Dearden's film Khartoum (1966), starring Charlton Heston as General Gordon and Laurence Olivier as the Mahdi. More recently it has resurfaced in print in In the Hour of Signs (1996), Jamal Mahjoub's postcolonial revisitation, and in Wilbur Smith's best-selling The Triumph of the Sun (2005), with heroines and sex very much in evidence. This is, however, as far as I can judge, an isolated episode. The post-9/11 political climate may have contributed to make the war against the Sudan Mahdyya an engrossing field of inquiry among historians and cultural historians, but does not seem to have precipitated a significant resurgence of the subgenre.

\section{Bibliography}


Arata, Stephen. 1996. Fictions of Loss in the Victorian Fin de Siècle: Identity and Empire. Cambridge: Cambridge University Press.

Ballantyne, Robert M. 1888. Blue Lights, or Hot Work in the Soudan: A Tale of Soldier Life in Several of its Phases. [1 volume] London: Nisbet.

Brantlinger, Patrick. 1988. Rule of Darkness: British Literature and Imperialism 1830-1914. Ithaca and London: Cornell University Press.

Bristow, Joseph. 1991. Empire Boys: Adventures in a Man's World. London: HarperCollins Academic.

Bulfin, Ailise. 2015. "To Arms: Invasion Narratives and Late Victorian Literature." Literature Compass, 12.9: 482-96.

Burleigh, Bennet. 1884. Desert Warfare: Being the Chronicle of the Eastern Soudan Campaign, with Official Maps. London: Chapman \& Hall.

Churchill, Winston S. 1899. The River War: An Account of the Reconquest of the Soudan. 2 vols. London: Longman.

Churchill, Winston S. 1972. Young Winston's Wars: The Original Despatches of Winston S. Churchill, War Correspondent 1897-1900, edited by Frederick Woods. London: Leo Cooper.

Coombes, Annie E. 1994. Reinventing Africa: Museums, Material Culture, and Popular Imagination. New Haven and London: Yale University Press.

Doyle, Arthur Conan. [1897/8] 2003. The Tragedy of the Korosko. London: Hesperus [orig. Strand May-December 1897; in 1 volume, Smith Elder \& Co.]

“Dr Conan Doyle's New Story." 1898. St. James's Gazette, (24 February) 5.

Floothow, Dorothea. 2007. "Images of War in Late Victorian War and Adventure Novels for Children." Cahier Victoriens et Edouardiens, 66: 129-49.

Fulton, Richard. 2009. "The Sudan Sensation of 1899." Victorian Periodicals Review, 42.1: 37-63.

Giddings, Robert. 1991. "Cry God for Harry, England and Lord Kitchener: A Tale of Tel-el-Kebir, Suakin, Wadi Halfa and Omdurman." In Literature and Imperialism, edited by Robert Giddings, 182-219. London: Macmillan.

Glazzard, Andrew. 2015. "Conan Doyle's The Tragedy of the 'Korosko': The Clash of Civilizations and the Necessity of Empire." English Literature in Transition, 1880-1920, 58.2: 164-80.

Hake, Edmont A. ed. [1885] 1984. The Journals of Major-General Gordon at Khartoum. London: Darf Publishers [orig. London: Kegan Paul, Trench].

Green, Martin. 1980. Dreams of Adventure, Deeds of Empire. London: Routledge and Kegan Paul.

Griffiths, Andrew. 2015. The New Journalism, the New Imperialism and the Fiction of Empire. Basingstoke: Palgrave Macmillan.

Henty, George A. [1892] 2000. The Dash for Khartoum. Mill Hall: Preston/Speed [orig. in 1 volume, Blackie and Son].

Henty, George A. [1903] 2002. With Kitchener in the Soudan. Cave Junction [orig. in 1 volume, Blackie \& Son].

Hough, Lewis. 1885. For Fortune and Glory: A Story of the Soudan War. [1 volume] London: Cassell.

Johnson, Douglas H. 1892. "The Death of Gordon: A Victorian Myth." Journal of Imperial and Commonwealth History, 10.3: 285-310.

Kestner, Joseph A. 2010. Masculinities in British Adventure Fiction, 1880-1915. Farnham: Ashgate.

Kipling, Rudyard. [1891] 1992. The Light That Failed, edited with an introduction and notes by John M. Lion. London: Penguin [orig. Lippincott's, January 1891; in 1 volume, Macmillan].

Krebs, Paula. 1999. Gender, Race and the Writing of Empire: Public Discourse and the Boer War. Cambridge: Cambridge University Press.

Le Queux, William. 1997. The Eye of Istar: A Romance of the Land of No Return. [1 volume] London: White \& Co. 
"Literature: Christmas Gift Books." 1885. Reading Mercury, (5 December) 7.

Luckhurst, Joseph. 2012. The Mummy's Curse: The True History of a Dark Fantasy. Oxford: Oxford University Press.

Mallett, Phillip. 2015. "Masculinity, Imperialism and the Novel." In The Victorian Novel and Masculinity, edited by Phillip Mallett, 151-71. Basingstoke: Palgrave Macmillan.

Mason, A. E. W. [1902] 2001. The Four Feathers, edited by Gary Hoppenstand. London: Penguin [orig. Cornhill; in 1 volume, Macmillan].

Neufeld, Charles. 1899. A Prisoner of the Khaleefa: Twelve Years' Captivity at Omdurman. London: Chapman \& Hall.

Paris, Michael. 2000. Warrior Nation: Images of War in British Popular Culture, 1850-2000. London: Reaktion Books.

Pollard, Eliza F. 1907. With Gordon at Khartum. [1 volume] London: Blackie and Son.

Richards, Jeffrey. 1989. "With Henty to Africa." In Imperialism and Juvenile Literature, edited by Jeffrey Richards, 72-106. Manchester: Manchester University Press.

Sharpe, Jenny. 1993. Allegories of Empire: The Figure of Woman in the Colonial Context. Minneapolis and London: University of Minnesota Press.

Steevens, George Warrington. 1998. With Kitchener to Khartum. Edinburgh: Blackwood.

Threlfall, T. R. 1901. The Great Magician. [1 volume] London: Ward, Lock \& Co.

Villa, Luisa. 2007a. "Nella terra del Mahdi: Il romanzo di avventura di ambientazione sudanese a fine Ottocento." In Emilio Salgari e la grande tradizione del romanzo di avventura, edited by Luisa Villa, 31-43. Genova: ECIG.

Villa, Luisa. 2007b. "The Breaking of the Square: Late Victorian Representations of Anglo-Sudanese Warfare." Cahier Victoriens et Edouardiens, 66: 111-28.

Villa, Luisa. 2009. "For Fortune and Glory": Studio sulle rappresentazioni sul conflitto anglosudanese. Genova: ECIG.

White, Andrea. 1993. Joseph Conrad and the Adventure Tradition: Constructing and Deconstructing the Imperial Subject. Cambridge: Cambridge University Press.

Zaccaria, Massimo. 1998. "Introduzione." In Joseph Ohrwalder, I miei dieci anni di prigionia. Rivolta e regno del Mahdi in Sudan, edited by Massimo Zaccaria, 5-26. Bologna: Editrice Missionaria Italiana. 